\title{
1 \\ From trickles to rivers of crime and freedom
}

\section{The essence of crime and freedom}

Chapter 12 argues that most of my propositions involve intertwined empirical claims and political claims that will always be resisted by those who hold power. Chapter 12 makes a pitch to young criminologists that they can lead satisfying intellectual lives by being politically serious. It is not really possible to be serious about reducing crime and expanding freedom without engaging with social movement struggles. Chantal Mouffe is an inspiration on being pluralist and agonistic rather than antagonistic. I hope this work stirs political passions in a Mouffe fashion.

Chapter 12 concludes that criminology has contributions to make to the survival of life on our planet. The combination of the criminalisation and militarisation of states and the rising cyber-sophistication of terrorism means that unintended nuclear war is a growing risk, not the fictional declining risk, post Cold War, of neoliberal triumphalism. This book shows that it is untrue that these risks are unknowable. They are known. Because they are complex nonlinear risks with feedback loops, however, we cannot estimate the probability of extinction events. For most people living comfortable lives in wealthy countries, climate change will not overwhelm them next year or even during this decade, though many poor people in Pacific Island states have already seen their homelands surrender to the tides. The risk of global famine and civilisational collapse from nuclear war may be small next year, quite small for the next decade, but multiplies to be high during the next century or two. Nuclear weapons 
are an acute danger in the hands of leaders like former president Donald Trump who countenance genocidal thought when they threaten to wipe Iran or North Korea from the face of the Earth. Former president Trump explicitly issued such thunderbolts. These are threats with tools of violence designed to be genocidal (Chapter 12).

Ecocide is at hand in the next century unless great powers like China, the United States and Europe learn to work together on better global and national regulatory institutions and green markets for a global Green New Deal (Tienhaara 2018; Drahos 2021; Braithwaite 2021d). Unfortunately, green markets are as prone to corruption as any other. As we have seen with the Covid-19 crisis, times of global crisis are particularly prone to criminalised markets. Fake Covid tests, untested vaccines and scientific fraud proliferated during 2020-21 in darknet markets. Chapter 12 also concludes that economic crises produced by criminalised markets, ecological crises and security crises conduce to crime-war-crime cascades. Hence, an immodest hope for this book is that it gifts our grandchildren glimmers of a politics and a social science of hope for surviving the next century. The United Nations has demonstrated that it can reduce the risks of ecocide through climate agreements (for example, closing the ozone hole). My empirical conclusion is that it has demonstrated that it can reduce war, reduce crime and support freedom through modest investments in peacekeeping. Therefore, the study of the impact of the United Nations and global social movements on crime and freedom is as central to macrocriminology as is the study of state policies. It is also pivotal to the kind of grassroots politics Jane Addams hoped we would continue. But as her Nobel Peace Prize citation warned: 'Those who set their sights on awakening and educating public opinion cannot expect swift victories of the kind that win popular acclaim' (Koht 1972).

The core argument of this book is that freedom is fundamental to building a low-crime society and crime prevention is fundamental to freedom. Sharp readers will detect this as partly tautologous. I define crime as conduct that threatens domination and then argue that crime increases domination and domination increases crime. Chapter 11 concludes that crime and domination are cascade phenomena. When crime and domination arise, they tend to reproduce instances of themselves. In the years of Covid, we all became that bit wiser about the science of contagion. Domination endogeneity and crime endogeneity (the topic of Chapter 11) are complemented by much exogenous explanation in this book and by domination-crime-domination explanations that reach beyond shared 
definitional features of crime and domination. For example, weak, distrusted states and weak, dysfunctional families allow both crime and domination to grow. Chapter 11 argues that criminology must become more comfortable with endogenous and exogenous explanation sitting side by side to explain recursivity in social change. Medicine also had that struggle. Too often it was insisting on external explanations in the air when the best explanation of disease was viruses reproducing themselves, even though an exogenous shock like the invention of a vaccine could reverse the dynamics.

Thin liberal freedom of choice-including the freedom to vote, choice in markets, freedom of movement and of religion - can contribute to crime prevention. Republican freedom as nondomination contributes much more. Republican freedom is a thicker freedom of the person, which Pettit (2012) juxtaposes with freedom of choice. It is freedom from being enslaved or dominated by arbitrary power. Narrowly conceived measures of inequality or poverty sometimes do not explain crime. The worst narrowing occurred in some of the thinking around US President Lyndon B. Johnson's 'War on Poverty'. It prioritised equality of opportunity to the neglect of the dominations of unequal outcomes. In recent decades, the inequality of outcomes has widened to pose deep dangers to the social fabric of societies and to global society. For most of human history, the richest societies were only twice as rich as the poorest and there were no wealthy business individuals who owned more than the richest kings, or more than many entire countries. These circumstances, I argue, are likely to drive further declines in trust in institutions and more authoritarian uprisings. A social democratic republican vision of simultaneously tempering all forms of domination, discrimination and inequality that drive domination can suppress crime and civilisational collapse. State-sanctioned discrimination (like slavery, Apartheid, inquisitions of religious heretics) has historically been the gravest threat to freedom, and the worst discrimination for driving crime and civil war. Nunn (2008) also found a robust negative relationship between the number of slaves exported from African countries and contemporary economic devastation. The domination of women in many societies is still infused with state-sanctioned discrimination. Hence, the thought of feminist republicans like Mary Wollstonecraft and Jane Addams is fundamental to free, low-crime societies that eschew war. 
Domination is advanced as a more fertile concept than inequality for explaining crime and violence. Militarised domination and criminalised domination of governments and markets are particularly destructive. Yet struggles against domination and discrimination do best when they are responsive to those inequalities that are subjectively salient at particular times and places. Micro-dominations (for example, between landlords and peasants, white police and black suspects, at tiny locales) can be more critical than national inequalities to explaining violence. Because it is hard to predict which levels or kinds of domination will fuel raging fires of subjective oppression and violence, and which will not, I argue that societies do well to aim at tempering all kinds of domination. It is common for multicollinearity to produce results that inequality explains crime, but poverty or racial discrimination does not; or that poverty explains crime, but inequality does not; or that child mortality but none of these other measures explains crime (Chapter 4). Often what is true in individual or ecological data is not true in time-series studies, or at least not true with short lags. We do best to read such literature with a spirit of openness to the domination effects that are socially constructed as oppressive at different times and contexts in different ways with different lags. Chapter 4 advocates wariness of a selective positivism that, after failing to find a particular linear effect, empowers analysis paralysis over inequality and domination.

\section{Not quite institutional balance}

Mark Colvin (2000) laid an important foundation for the domination focus of this book with his theory that 'coercion causes crime and social support prevents crime' (Colvin et al. 2002: 19). There is special appeal for the responsive theoretical framework of this book in the specificity with which Colvin (2000: 26) defines social support as 'responsiveness to the needs and desires of others'. Gerald Patterson's (1982) Coercive Family Process showed that coercive discipline in families conduces to crime. This was an important insight for Colvin's work. Colvin is relational in how he thinks about social support. Coercive controls of diverse kinds produce an alienated bond between the controller and the controlled. Children who have been heavily coerced in families and schools carry their alienated relationality into workplaces, militaries and marriages. Tittle (1995) takes up a cognate approach to evidence that 'control balance' explains crime. Robert Agnew's (1992) empirical insight is that it is erratic coercion- 
especially arbitrary and unjust treatment that is perceived as arbitrary and unjust-which produces extreme other-directed anger and high rates of crime. This is one motivation in explanatory theory for the move in this book from the concept of coercion to domination-defined as not just any kind of power over another, but power that is arbitrary and unjust.

Republican freedom requires richer separations of powers, both public and private, than we see in western societies. Sun Yat-sen's vision of pluralising the separation of powers more deeply than in Montesquieu's thinking is a light on my republican hill. It draws on ancient Chinese thought about institutions. Ancient thinking about anomie also originated in the East, travelling to the West through Persia, Babylon, Greece and Rome, with the most important modern thinking about anomie being French-that of Durkheim and Montesquieu. Ancient anomie arises when there is no agreement on norms about living together, and no agreement about which institutions should have the authority to set those norms. Anomie means want of a social fabric of shared understanding about which forms of power are arbitrary and intolerable. These are central themes of Confucian thought.

Anomie Américaine took splendid strides towards macrocriminology in the twentieth century. This flowed in a lineage from Merton to Cloward and Ohlin, Cohen, Messner and Rosenfeld, with help from many others. We have seen that anomie ancienne is also institutional. Yet anomie Américaine has come to be known as institutional anomie theory because it points to the need to strengthen many institutions, particularly to check and balance the burgeoning dominations of market power. This book radically expands the palette of institutions that must be strengthened by a strong state, strong civil society, strong markets and strong, agentic individuals. It also diverges somewhat from Messner and Rosenfeld's institutional anomie theory in conceiving of strengthening markets as fundamental to a freer, lower-crime society.

For example, the book argues that dominations of the financialisation of capitalism must be contested by new financial institutions that contest domination by big banks. This includes new ratings agencies that might be competitors to the likes of Moody's. Such market competitors might sometimes be publicly owned, with a charter of contesting extant market dominations. The dominations of tech giants must be contested by more market competition from competing platforms as well as tempered by more state regulation. People understand the model of how the BBC in 
Britain or the $\mathrm{ABC}$ in Australia provide competition to the dominations of media barons like Rupert Murdoch as public broadcasters with a charter of political independence and investigative journalism. In some geopolitical contexts, the needed contestation of tech giants that suck the life out of professional journalism may be market competitors that are publicly owned platforms - an option raised with me by RegNet colleague Jensen Sass-or the kind of enforcement actions that have been signalled by the Australian Competition and Consumer Commission (ACCC) against monopolistic surveillance capitalism (Zuboff 2019). Contra institutional anomie theory when it is narrowly conceived, markets in crime-control strategies are important to crime and freedom, especially to corporate crime prevention. They are important to preventing bank robberies and car theft, too (Farrell et al. 2014; Weatherburn and Rahman 2021). A central idea of this book is that republicanism supplies a normative theory that distinguishes markets in virtue from markets in vice. Markets in vice increase the quantum of domination in the world; markets in virtue reduce domination.

Acemoglu and Robinson (2019) convincingly show that the reason the Dutch Republic and Britain evolved into freer, less-dominated societies than Spain and Portugal from the seventeenth century was that Spain's and Portugal's international trade were controlled by state monopolies. Spain and Portugal therefore sustained profound incentives for patrimonial state domination through elite networks. Private market entrepreneurs from Britain and the Netherlands, in contrast, were the actors who had seized the initiative to build national wealth through international trade. These were key actors behind England's Glorious Revolution of 1688 that took big early steps towards humbling the domination of kings through a parliament and a mixed constitution. This was also true of Switzerland as an example of a smaller, landlocked society with formidable state, business and civil society capacity (Acemoglu and Robinson 2019: 278-79; Adler 1983). Britain, the Netherlands and Switzerland became comparatively free, very wealthy, low-crime societies. Constantly emerging new elites were therefore always contesting the domination of old elites, demanding concessions towards balancing a mixed constitution. Acemoglu and Robinson draw a variety of other comparisons of this kind between societies that were similar in most other important respects apart from the growth of powerless little businesses into more potent private-sector 
actors who could check state domination. Another such contrast was the liberal republicanism of Costa Rica versus the despotism of Guatemala (Acemoglu and Robinson 2019: 193-302).

Then Acemoglu and Robinson (2019: 284) moved from state despotism contested by a bourgeoisie which emerged through markets, to contestation of despotism by the lowest classes. They argue that the Black Death so devastated peasants in fourteenth- and fifteenth-century Western Europe (less so Eastern Europe) that there was a critical shortage of manual labour (in Western but not Eastern Europe). Serfs felt empowered to challenge the feudal order by walking off the manor when their lord refused them a better share of the fruits of their labour. They moved to work for another master who offered less domination. In the long run of history, peasants became more organised as their demands evolved within markets into creation of the trade union movement. During the nineteenth century, incipient trade unions became powerful enough to demand that the vote should not be restricted to landowners. Ultimately, this empowered the working class to form social democratic and socialist political parties that won elections. The second great impetus towards this enhanced market power of manual workers was the Industrial Revolution that accelerated in the nineteenth century to empower peasants to walk off their estates to seek factory work. Factories and mines concentrated industrial workers, making political organisation more feasible to contest domination by the aristocracy and the bourgeoisie alike. In all these ways, markets enabled the contestation of domination at the same time as markets constituted new forms of domination that drove the depth and spread of inequality to levels never seen before.

Many of the poorest societies on the planet remain afflicted by exclusionary patrimonial domination because they are yet to have their power contested by the market power of either a rising middle class or a rising trade union movement. Uplift of these forms of market contestation of domination is fundamental to republican nondomination. These supranational dynamics of the contestation of feudal power are also a key to understanding why feudalism continued to dominate so many Eastern European societies until Napoleon's armies and France's legal code abolished feudalism. Feudalism outlasted Napoleon in many societies, however. Hence, during the centuries when democratic traditions became embedded in Western Europe, despotism became more deeply institutionalised in much of Eastern Europe and the Ottoman Empire. Acemoglu and Robinson (2012) even describe how the Habsburg and Russian empires sought to 
preserve their domination from the infrastructural impetus to trade that railways provided by resisting them and preventing the dissemination of other infrastructural industrial technologies. The Qing government in China purchased the first railway built in that country in 1870 by the British firm Jardine, Matheson \& Co. and tore it up (Acemoglu and Robinson 2019: 226). This was of a piece with a long, intermittent history of Chinese dynasties banning international trade by ships, and other mercantile activities and technologies that Chinese regimes conjectured could destabilise the social order they dominated. Such antibusiness politics was why states like the Netherlands and Britain that enabled business growth surpassed the previous geopolitical dominance and wealth of China for the first time during late modernity.

There is a difference between this book and Tittle's (1995) idea that there is an optimal control-balance ratio that produces low crime, and Messner and Rosenfeld's (2013) idea that institutional balance is associated with low crime. Messner and Rosenfeld believe that 'institutional imbalance ${ }^{1}$ is positively associated with the level of crime' (Stephen Messner, personal communication commenting on this book). That can be true. At times there might be, as Rick Rosenfeld put it to me, a 'difference without a distinction' between my analysis of balance and theirs.

Yet I want to insist that the worst political errors achieve balance by weakening strong institutions. The worst socialist errors weakened markets; the worst Thatcherist errors weakened the state. My interpretation of balance goes to strengthening weak institutions. I argue that separated

1 Acemoglu and Robinson (2019) are even more explicit about favouring an equal-power view of the balance between the powers of different institutions. In contemplating that, readers may ask themselves, even if they understand what equal institutional power means, would they necessarily agree this is better than one institution having 10 or 30 per cent more power than some other institution in some circumstances? The equality formulation starts with Acemoglu and Robinson's (2019: 13-14) attraction to the ancient Sumerian intuition in the Epic of Gilgamesh found on 4,200-year-old tablets. They return to Gilgamesh throughout their book. Gilgamesh was the King of Uruk in what is today Iraq. Uruk was perhaps the world's first city. Gilgamesh was a despot. He created a wealthy city, but in time became so out of control that the citizens of Uruk appealed to their god: 'Create a double for Gilgamesh, his second self, a man who equals his strength and courage, a man who equals his stormy heart. Create a new hero, let them balance each other perfectly, so that Uruk has peace' (Acemoglu and Robinson 2019: 14). Acemoglu and Robinson articulate their ideal as a 'contained Leviathan', while I opt for Krygier's (2019) tweak of 'tempering' that makes states and markets stronger, as opposed to containing them in pursuit of balance. We certainly favour many of the same policies; nevertheless, as I pursue balancing to temper power, they pursue balance that contains power, 'controls' it, 'shackles' it. The perspective of Acemoglu and Robinson (2019: 16-17) that I endorse is when they say: 'When the state and its elites are too powerful and society is meek, why would leaders grant people rights and liberty? And if they did, could you trust them to stick to their word?' 
institutional powers must be able to pursue power up to the point where the power of one institution cannot overwhelm the power of the others. Each separated power must be strong enough in its countervailing capacities to secure the exercise of its own power from being dominated by any other institutional power. I argue that more freedom and less crime can be accomplished by all institutions continuing to grow their capacities to deliver those outcomes, while they also check and balance all institutions from dominating others. This is one way I interpret Martin Krygier's (2019) concept of tempering power. The aim is for a free society in which all institutions continually grow stronger and continually grow their capacity to temper one another. It is not for a society with any optimal institutional balance. This also distinguishes Pettit and my normative framework from that of libertarians; libertarians want the state to be weaker so markets can be stronger. Conversely, socialists want markets to be weaker so the state can be stronger. Like Krygier, I argue that republican social democrats should want to grow both ever stronger and ever more tempered. What I share with Messner and Rosenfeld is the aim of many other institutions growing on that trajectory as well.

For all the richness of insight I find in Acemoglu and Robinson (2019), as with Messner and Rosenfeld, I conceive of them as advocating more institutional 'balance' in many circumstances when they would do better by freedom and crime control to strengthen weakened institutions rather than achieving 'balance' through weakening one kind of institution or another. We see this with Acemoglu and Robinson's (2019) persistent return to the importance to freedom of breaking down the 'cage of norms'. This book is very much about how to improve collective efficacy to make norms work better. When they do, they strengthen our wings and liberate rather than cage us. That is not to deny the many good points Acemoglu and Robinson make about domination caused by norms that form a cage. The fact is there are good and bad norms. This is true whatever your normative theory of the good and the bad is; for Pettit and me, good norms are those whose application reduces domination; bad norms increase domination. Chapter 3 argues that western justice took a wrong turn from the moment kings found it helpful to conceive of crimes as offences against the crown (which later morphed into crimes only against the state). Kings found the power to seize the lands of criminals politically attractive. By moving away from the idea that crimes are also against victims, who deserve compensation, kings crushed moot traditions with legal formalism. This error is being repaired today by restorative justice 
advocates who argue for legal formalism that empowers informal social control and informalism that empowers legal formalism. What we want is legal formalism that checks domination by the 'cage of norms', and informal restorative justice institutions that check domination by courts, police and presidents (when they pardon powerful state criminals). We will see that the latter are particularly critical with state denial of international crimes, where citizens' tribunals had to step in on matters like systematic rape by the Japanese military (of rape victims called 'comfort women').

Acemoglu and Robinson (2019) are right to point out that informal institutions like Germanic moots or panchayats (village councils) in ancient and modern India were ripe for domination by whoever were the local ruling class or the elite caste. It is hard to find examples of tribal informal justice that are not dominated by males and not biased in favour of male interests, excluding even the wisest female elders of the tribe. Ali Wardak, reflecting on male domination of jirgas (tribal assemblies) in Afghanistan, argues that the better path to freedom and justice for Afghanistan is to strengthen such male-dominated tribal justice institutions. Empirically, they enjoyed much more confidence from the people than corrupt state courts. At the same time, Wardak argues, it was possible during the 20 years after the 2001 western invasion of Afghanistan to strengthen countervailing women's jirgas that enjoin male jirgas in justice conversations and contestation. In addition, Wardak advocates contestation of the justice of jirgas by the Human Rights Commission, which happened to be a female-dominated institution in Afghanistan until 2021 (Wardak and Braithwaite 2013). Wardak's idea was to ensure the agents of women's rights who contest male agents of the jirga were female agents of the Human Rights Commission. What is missing from Acemoglu and Robinson's (2019) analysis here is an understanding that judiciaries and police forces, even in liberal western democracies, were also almost totally male institutions until the late twentieth century. In a country like India, it has proved easier to pass a national law that requires one-third of those who preside in the informal justice and informal village policymaking of panchayats to be female (the 1992 Panjayat Raj constitutional amendment) than it has to pass a law that requires onethird of judges to be female. Why? Because male judges can mobilise more national power to defend their privilege than can male panchayat members, who enjoy only village power with little national clout. 
All that said, male agents of formal justice systems can be and are important to checking criminal abuses of male power. This is true with Ali Gohar's program on hybrid jirgas in Pakistan (Braithwaite and Gohar 2014), at which male police (who always attend) are trained to protest if it is proposed that a young woman be given as a bride to reconcile a blood feud. Police are trained to assert that this is against national law, against sharia law and against the policy of this restorative justice program. Those male police are a significant check and balance for women's rights, though much less important in the analysis of this book than feminist social movement politics. I argue that the most historically potent check against the cage of patriarchal norms has been feminist norms promoted by feminist politics.

Acemoglu and Robinson (2019) actually agree that strengthening rather than loosening certain informal norms is important to defending freedom. They also agree that checked and balanced state power-which Krygier (2019) would say is tempered-develops deeper state capacity. So, why use language that plays into the hands of legal formalists who seek to abolish informal justice; why use language that plays into the hands of libertarians who are opposed to deeper state capacity? I prefer the concepts of Acemoglu and Robinson (2019: 73) when what they value are 'capable states matched by capable societies'.

The bottom line here is that quite often I find myself thinking as I read the work of Acemoglu and Robinson (2019) and Messner and Rosenfeld, 'no, it is not more "balance" that is needed here but more checks' (in their elusive checks and balances formulae). A problem with Acemoglu and Robinson (2019), Messner and Rosenfeld and most thinkers about checks and balances (including me) is they do not have a clear enough view of how much balance is balance. It is better to be more cautious in usage of the balance concept. Better to advocate making all institutions that are useful to freedom stronger, including the 'cage of norms' (the particular bête noire for Acemoglu and Robinson) and markets (the bête noire of Messner and Rosenfeld). How much stronger? They should be as strong as they can be without dominating other institutions; as strong as they need to be to defend themselves from being dominated by other institutions (which involves a mix of balancing and checking); as strong as they must be to make the best contribution they are capable of making to reducing the amount of domination in the world. In the same manner as Chapter 9's conclusions about how to iterate towards reduced criminal punishment, any responsive journey towards continuously improved 
strengthening, checking and balancing of institutions involves endless iterative adjustment. This responsive adjustment fosters learning as global and local conditions change.

\section{Recursive republican social science}

'There is something deeply ironic' about the fact 'that from the life-changing experience of an entirely unexpected, nonlinear event like the end of the Cold War', the West 'has derived a thoroughly linear expectation of the future'. (Thomas Bagger, quoted by Krastev and Holmes 2019: 90-91)

While this book conceives of stronger markets in virtue as vital to the control of markets in vice, its mission is to tweak and integrate anomie ancienne and anomie Américaine under a republican politics of hope. Republicanism has older roots than liberalism in America and Europe, the East and the West. It has more radically redistributive social democratic implications than modern liberalism. These wider social democratic implications have been richly developed by Philip Pettit (1997, 2012, 2014; Marti and Pettit 2010), building on our ordered set of propositions for a republican theory of criminal justice (Braithwaite and Pettit 1990). Subsequent publications cited herein elaborate this republican normative thinking to apply to regulatory questions with big implications for freedom. This is not a political philosophy book that labours those older foundations, but one that develops a list of 150 corollaries from a convergence of empirical propositions about crime and republican normative propositions elaborated from their initial explication in Braithwaite and Pettit (1990). The opening pages of Chapter 2 resume these themes.

Domination's deepest threats to freedom and crime occur when commanding-heights institutions—-states and markets-are criminalised. These are not distant threats. Donald Trump's presidency was taking the United States well along a trajectory towards criminalisation of the state and criminalisation of markets. Similarly, long-cherished republican visions have been overthrown in diverse European states and by Turkish President Recep Tayyip Erdoğan's overturning of eastern leadership towards republicanism at the heart of what was the Ottoman Empire. This Turkish republican shift evolved erratically across the half-century following the government led by Kemal Atatürk from 1920 to 1938. This 
book argues that to contemplate the full violence of the criminalisation of states and markets, we might look hard at Democratic Republic of Congo or Jamaica. These were once flourishing democracies that were leaders of their regions in economic development, poverty reduction, modern culture from rumba to reggae and sporting excellence from sprinting to cricket. They have had their freedom ravaged this century by criminalisation of states and markets. Differences among societies across space and time are massive on these variables. These differences are at the centre of the theory of freedom and crime. Hence, the priority is clear for a more micro-macro criminology to repair criminologies that have denuded macro traditions since their zenith at the time of Edwin Sutherland in America and Willem Bonger in Europe.

Macrocriminology that is rich in insight is recursive and paradoxical in its explanatory approach. It resists linear conceptions of a civilising process, even as it admires Norbert Elias (1982) for grappling with ideas about societies becoming less violent as they craft institutions that temper the emotions, and institutionalised normative order. The evidence is strong that transitions to democracy and nondomination give rise to anomie, to high rates of crime and to heightened risks of civil war (for example, Zhao and Cao 2010). Crime, violence, substance abuse and self-harm are fundamental to understanding why, as in most of the Soviet Union and Eastern Europe, life expectancy in Russia plummeted from 70 years in 1989 to 64 in 1995 on the back of 1.3-1.7 million premature deaths (Krastev and Holmes 2019: 90-1). America's birth as a republic and its transition from slavery testify to the terrors of crime-war-crime cascades involved in transition to freedom through a revolutionary war, a frontier war against indigenous Americans and a civil war that scarred the society with criminogenic legacies.

Martin Luther King Jr and Mahatma Gandhi had the acute insight about how to be effective in struggles against domination—as did Angela Davis, who still shines as a contemporary light on the hill of the restorative justice movement. The evidence is now potent that when struggles against domination are advanced nonviolently, they are more likely to prevail politically and are more likely to leave a legacy of freedom in the aftermath of the struggle to destabilise the old order of domination. The paradox of 'destabilisation rights' and anomie is not the hard paradox of violence advanced by thinkers like Frantz Fanon in Algeria and Che Guevara in Argentina and Cuba. It is a paradox softened by the empirical discovery that patient, long-term, nonviolent social movement struggles against 
evils like slavery, ecocide and genocide—indeed, against war itself-are the struggles that advance freedom and subdue crime. This book has not theorised this as fully as it ought. A future book after data collection ends in 2030 will deploy the Peacebuilding Compared database to range in a more fine-grained way, case by case, across South Africa, India, Algeria, Sudan, Egypt, Iran, the Philippines, Timor-Leste, Indonesia, Korea, Myanmar, France, Russia, China, the United States and more, to study the history of violence and nonviolence in destabilisation rights. A key question is how social movements for nonviolent struggle against domination should negotiate with militaries to avert militarised societies in the washup, so violence does not cascade across the next century.

\section{Learning from Sun Yat-sen}

One political leader greatly influenced by Gandhi was Sun Yat-sen. He became the first president of the Republic of China after his republican movement overthrew the last dynasty, the Qing (Manchu), in 1911. Dr Sun wanted a China that was a force for peace in the world. $\mathrm{He}$ transacted his practical politics with grace and personal kindness to collaborators and adversaries. The peaceful aspect of his thought is not without influence in contemporary China, which, while its state increasingly throws its weight around, has had less of a penchant for invading other countries than the great western powers and Russia since 1911, indeed since 2001. Paradoxically, the social democratic aspects of Sun Yat-sen's philosophy were also not without influence in Chiang Kai-shek's despotic anticommunist regime in China, then Taiwan. Partly in homage to Sun and his following after death, partly from fear of the appeal of communism to Taiwan's peasants, from 1949, Taiwan enacted one of the most successfully redistributive land reform programs of any country (You 2014). It gave impoverished peasants a greatly increased stake in Taiwan's comparatively egalitarian market economy.

We can see from Sun Yat-sen's lectures on his 'livelihood' principle that he was a leading social democratic thinker a century ago (Wells 2001: 91-97). A priority was liberation from colonial yokes - many of them, in the case of China (Linebarger 1937). He was a pracademic who sought to build the society of his philosophy through republican social movement politics. Sun Yat-sen is uninfluential in western political philosophy not only because western philosophy is so closed to influence from eastern 
and southern thought, but also because after he fell ill with cancer in his 50s, he made time to systematise his scattered and sometimes inconsistent political philosophy. These manuscripts were destroyed in a 1922 bombardment of Sun's headquarters by an opponent with imperial ambitions, Chen Jiongming, and the Merchant Volunteer Corps funded by Hong Kong and Cantonese bankers whom Sun fought until his death in 1924. Sun ran out of time to rewrite these chapters, but did manage to present 16 of 18 of them as hastily prepared lectures with which he was dissatisfied because he could not access the books he needed to prepare them a second time (Wells 2001: 62). Given the way the financialisation of capitalism became such a threat to redistributive social democracy, there is poignancy in the burning of these manuscripts by forces backed by bankers. The sad fact of most western philosophers is that few bankers would find it worthwhile to bomb them and burn their manuscripts.

Sun's constitutional thought was more radically democratic than that of republicans like Philip Pettit $(1997,2012,2014)$ (or me). His republican constitution for China conceived of the vote as just one of four forms of direct accountability to the people by election, recall, initiative and referendum (Linebarger 1937: 211). When he visited the United States more than a century ago, he was less than impressed by the populism of its elected politicians. He perceived many as stupid, others as corrupt, with the system putting too much emphasis on entertaining oratory (Wells 2001: 36, 81). His philosophy was Confucian in the belief that rulers must be learned, well educated, temperate, competent, as well as deeply accountable to ordinary people who will not be so educated, mostly peasants. This is why he continued to believe, when so few had higher education, in the Confucian institution of a (fourth) examinations branch of government to complement Montesquieu's tripartite separation of powers among a legislature, executive and judiciary. Chapters 3 and 8 discuss the greater import of Sun Yat-sen's fifth branch that became part of his constitution for the Republic of China (still partially implemented in Taiwan). This was an independent accountability and integrity branch that oversaw impeachment of the kind of venal and populist politicians who worried Sun in America, but also the impeachment of judges and senior members of the executive government. Its independence ideal (in Thailand as well, as discussed in Chapter 8) came to be secured by elected members of the accountability branch having no affiliation with political parties in the legislature and serving for only one term. This separated accountability branch also had the function of overseeing 
business regulatory institutions and regulators of the state itself such as the auditor-general, the human rights commission, the ombudsman, the electoral commission and the anticorruption commission.

It is easy to see, therefore, why Sun Yat-sen's innovations in pluralising the separation of powers are such an influence on how I think about Martin Krygier's (2019) tempering of power as central to crime prevention. His approach shows a better path for states to impeach the most criminalised members of their own state elites with decisiveness and political independence. Sun Yat-sen's redistributive social democratic politics was attractive for the purposes of this book, as was his commitment to maximally nonviolent means of pursuing power through republican social movement politics, his commitment to strong markets as vital for a strong China and his belief that a strong state (albeit a democratically accountable one) was necessary to subdue forces loyal to the Manchu Dynasty, to warlords and to triads who ravaged China for more than a century. His enemies in business characterised his commitment to a strong Chinese state as an intention to subdue liberty. Sun made many mistakes. His opposition to the Manchu Dynasty at times fuelled a Han Chinese nationalism that cascaded to violent racism against ethnic Manchurians (and Mongolians). This has legacies today in communist China's oppression of these minorities and is relevant to understanding the Han nationalist dimensions of the oppression of ethnic Uyghurs in Xinjiang.

Sun Yat-sen's greatest failing, however, was not understanding that his commitment to tempering power needed to be more total than it was. $\mathrm{He}$ allowed his movement to be seduced by one strand of Lenin's thought: the idea of a vanguard party (the Kuomintang for Sun Yat-sen) that would have to govern for a short period (until 1935, he suggested, though he flip-flopped awfully on this timing under Soviet pressure). The vanguard party would have limited accountability checks until it totally subdued the military power of the Manchu Dynasty and the warlords. Sadly, that Hobbesian transition to republicanism never blossomed beyond unaccountable Kuomintang and communist tyrannies. We do not know the inner workings of Sun Yat-sen's mind on this, but it could be that he was not actually seduced but tricked by Lenin's political guile in circumstances of Sun having few options. Sun wanted his republicans to rise to power with support from western democracies. The bankers who burned his manuscripts were among business interests who persuaded western leaders that his land-reforming, redistributive, anti-imperialist policies were dangerous. Without the western support Sun Yat-sen craved to keep his republican revolution afloat, 
he accepted the generous offers of material support volunteered by Lenin. Communists were also a radical flank of his republican movement in the way they were later in the century for Nelson Mandela in South Africa and Xanana Gusmão in Timor-Leste. So long as Sun's republicans allowed the communists a voice within the movement, republicans attracted increasing support from Lenin. Mao Zedong respected Sun Yat-sen, found great appeal in his redistributive land reform proposals for the liberation of peasants and joined his movement. The more the West spurned republicanism, the more Lenin's agents in China succeeded in targeting promising young republican leaders like Mao to flip them to communism. That is the background for a discussion of macrocriminology and freedom in contemporary China in the next chapter.

The tragedy of Sun Yat-sen is that after his premature death from cancer, two factions crystallised: the Nationalist Kuomintang under Chiang Kaishek, who attracted western support by throwing the communists out of the republican movement; and the communists, who ultimately fell under the all-conquering Mao. One became a despotic regime of the right, the other a despotic party of left. Both tragically put Sun Yat-sen's transitional unaccountability of party rule to work for their opposing projects of dominating the people of China. It mattered little that Sun Yat-sen conceived of his transitional party hegemony not as a 'dictatorship of the proletariat', but as a period constrained by specified dates when the people would be educated in democratic norms as preparation for full constitutional democracy. ${ }^{2}$ His political error remained the fatal one of creating a transitional structure of party domination sufficiently long for his despotic successors to secure enduring domination by regimes that supplanted the Manchus and warlords. A lifetime after Sun's death, both unaccountable parties continued to rule their regimes. Martial law was not replaced with democracy in Taiwan until 1987 . One day mainland China may also more fully imbibe the liberation from despotism that was Sun Yat-sen's project.

2 Actually, Sun's writing conceived of three stages of transition from dynastic rule: 'Period of Military Operations; (b) Period of Political Tutelage; (c) Period of Constitutional Government ... During the period of military operations the entire country should be subject to military rule. To hasten the unification of the country, the Government to be controlled by the Kuomintang should employ military force to conquer all opposition in the country and propagate the principles of the Party so that the people may be enlightened ... The period of political tutelage in a province should begin and military rule should cease as soon as order within the province is completely restored ... To enable the people to be competent in their knowledge of politics, the government should undertake to train and guide them so that they may know how to exercise their rights of election, recall, initiative, and referendum' (Sun Yat-sen, quoted in Linebarger 1937: 211). 
Sun's project was about ending a century of anomie and terrible wars in China and ending the criminalisation of the state and of markets that came with defeat by the British in the Opium Wars. In reality, however, his republican revolution started another four decades of civil war that created the opportunity for Japan to start World War II in China in the 1930s. In the aftermath, two different kinds of criminalised states were created, under Chiang Kai-shek and Mao Zedong, which could launch a project with as large a criminal imagination as interring a million Uyghurs today just for being Uyghurs.

This book argues that Sun Yat-sen was right to want a strong state, strong markets and a strong republican movement. His folly was being too half-hearted about the separation of powers or, rather, too staged about transition to his more full-hearted commitment to separations of powers, compared with other republicans. Chapter 8 develops Timor-Leste as a twenty-first-century case of other great social democratic leaders making quite similar mistakes during periods of transition. The Timor-Leste story has a happier ending because UN peacekeepers came to its rescue when war and tyranny began to take off in Timor in 1999 and again in 2006. It is important to see that possibility for a low-crime republic to be brokered peacefully with UN support in Timor-Leste in the washup to a genocidal civil war. Had it been possible for UN peacekeepers to pacify the warlords, the Manchus and others with imperial ambitions such as the bankers, who were still ravaging China in the early twentieth century; if a UN transitional administration had supervised a free election at that time, Sun Yat-sen would have been elected president. If there had been the impossible dream of a UN-supervised constitutional convention, the constitution adopted would probably have been something like Sun Yatsen's five-branch republican constitutional vision. There was no United Nations on which Sun Yat-sen could lean. That was an impossible dream. Timor-Leste illustrates in Chapter 8 that this is a possible dream for a republican social democracy today.

Hindsight is glib when political transitions are so fraught for leaders like Sun and Gusmão. They were militarily weak in confronting massive Chinese and Indonesian armies, respectively. Their only chance was to be diplomatically strong if they were to avert endlessly futile civil war. UN Security Council guarantees of peaceful transition with UN peacekeepers is a luxury Sun might have used to make transition work. Sun was a supporter of the League of Nations and initially optimistic about it, but he was disillusioned by the way colonised nations were marginalised and 
disrespected by western leaders at Versailles. Western thought has been too self-obsessed to look back on this as another historically devastating mistake born of Allied arrogance and will to domination at Versailles.

None of this is to say that UN peacekeeping is usually a midwife to an imperfect yet republican democracy, as it was in Timor-Leste. Usually, it is not. There are more experiences like that described by Broadhurst et al. $(2015,2018)$ for Cambodia (Chapter 3$)$. We will see that UN peacekeeping did bring peace and a steeply lower crime rate in Cambodia. These are not accomplishments to sniff at. But the Cambodian low-violence society today is one in which the successor regime to the genocidal Khmer Rouge is only somewhat less despotic, led by a senior Khmer Rouge defector, Hun Sen. The regime honours rituals of democratic elections to placate the United Nations but delivers no democratic substance under its enduring one-party rule.

Do not despair, is my message to young, politically engaged criminologists. Yes, the despot Hun Sen inherits power, but his domination is somewhat less than that of the Khmer Rouge, and citizens there live in less fear of violent crime. The more redemptive path of Timor-Leste is also a low-crime and low-domination possibility (Chapter 8). Finally, Sun Yatsen's life as a pracademic was far from wasted inside China. Democracy has finally arrived in Taiwan and it builds on a foundation of land reform that accomplished a society with a structurally low Gini index in land and wealth inequality. It is a democracy where remnants of Sun Yat-sen's fivebranch constitution mean more leaders are impeached in Taiwan than in the United States, as was Sun's hope (Chapter 8). China may remain tyrannous and violent for Uyghurs. For Han Chinese, however, they live in less fear of warlords, drug lords, foreign armies and violent crime than they did before Sun Yat-sen's republicans confronted the structures of violence, even if they live under the domination of the Communist Party.

One Sun Yat-sen vision that was not totally burnt by bankers was reforesting northern and central China (Linebarger 1937: 251). A century on, it is finally being realised. The Green Great Wall plan is to plant 88 billion trees along a 4,800-kilometre frontier to hold back the expansion of the Gobi Desert. It is well under way, as is Chinese help for Africa to arrest desertification with Africa's Great Green Wall at the southern extremity of the Sahara. A Nature article reveals this afforestation is building a renewed Chinese carbon sink that in the past has been underestimated and now absorbs 45 per cent of estimated annual Chinese anthropogenic emissions (Wang et al. 2020). 
While I have been able to find only one article in any philosophy journal about the political philosophy of Sun Yat-sen (Gregor 1981), there is hope in looking forward to a more intellectually plural academy that takes the thought of Sun Yat-sen seriously. Sun reveals ways to help all societies experience less crime with more freedom, as argued in Chapter 8. The next generation of young criminologists in China, Taiwan, Hong Kong, Thailand, Vietnam and Indonesia might renew the interest in the constitutional thought of Sun Yat-sen that has never been totally extinguished in those societies.

Reading this shortened narrative of the life and thought of Sun Yat-sen makes it easy to understand why many commentators write him off as a political opportunist who made a mess of things (Bergère and Lloyd 1998: 4-5). My narrative also makes it easy to understand why critics conclude his political philosophy is an incoherent hotchpotch of checks on the strong (allegedly illiberal) state he sought. Like Thomas Jefferson with his 600 slaves, it is true that Sun was no feminist; he was Confucian in valuing strong families much more than strong individuals who could stand up to families. Nevertheless, the 1890-1920 period of his republican revolution did permit a space of sufficient freedom for the blossoming of a Confucian vernacularisation of feminism (Li and Ackerly 2021) that I will argue in Chapters 2 and 3 created superior conditions for progress of the empowerment of women during most of the twentieth century in China than were seen in the West. I hope my narrative helps westerners understand why two Chinese universities bear the name of Sun Yat-sen - one of them among China's very best-and why another, in Moscow, is quaintly named The Sun Yat-sen Communist University of the Toilers of China. I hope we might see Sun Yat-sen as a kindly visionary who walked his republican talk, a social democrat who shone a faltering light of freedom from the hill of his Nanking republic where he rests, who remarkably managed to launch from social movement politics to become the first president of the Republic of China. He accomplished this without an army, through a revolution with little bloodshed.

Sun knew, however, that without control over a national military in a militarised society, and without international support in 1911, his republican government could not hold. After 45 days, he stood aside as president for one leader after another who could command more western support (but less Chinese legitimacy than Sun, and more Soviet opposition after the Russian Revolution). They failed. The warlords ran rampant, carving up local control of the country until Mao Zedong was able to unite China to defeat Japan and all internal enemies by 1949 . The greatest failings were the avarice and bloodlust of the warlords 
internally, rapacious western powers and Japan, which also wanted to carve up China's wealth and territory for their imperial designs, and Soviet power that sponsored takeover by communist tyranny. I know my interpretation of the life, politics and constitutional thought of Sun Yatsen will generate enthusiasm in neither the West nor China. The latter was clear from speaking in Beijing and having a Communist Party leader jump up to explain that Dr Sun was a great revolutionary, but Braithwaite's interpretation of his contribution was not the correct one! Even so, for the analysis of this book, it is the right provocation of the great powers to catalyse conversations between them about their responsibilities to prevent the extinction of both their civilisations.

\section{One hundred and fifty propositions about crime and freedom}

Each chapter that follows lists its key propositions. There are overlaps in the character of the propositions discussed in different chapters. A virtue within that vice is that we can induce from the list of specific propositions aggregated in Appendix I a shortlist of more general ones. Readers might choose to glance at bits of Appendix I that interest them before moving to Chapter 2. This will give you more of a feel for the complex of threads that weave together the fabric of the book. Without getting a feel for the holism of the set of 150 tributary propositions in Appendix I, and how they are sequenced, it is a challenge to grasp the significance of the six propositional rivers into which those tributaries run. Indeed, I worried that readers starting with the six abstract propositions rather than the 150 tributaries that constitute them might view the six as banal and overly abstract. It is in the 150 strands of the fabric that the analytic edginess found in the pages of this book is integrated into a normatively and empirically testable shape.

The parsimony of the six proposed rivers of transformation comes from them all being normative propositions. Normative propositions more readily lend themselves to overarching principles that cluster. The six rivers of my argument are:

1. Reduce all dimensions of domination.

2. Separate and temper powers.

3. Strengthen institutions of the market, state and civil society, and strengthen individuals. 
4. Maintain a normative order that nurtures collective efficacy to resist domination.

5. Strengthen financial capital, human capital, social capital, recovery capital and restorative capital.

6. Prevent wars before they begin to cascade violence, anomie and domination.

The reason this is an explanatory and normative theory of crime and freedom is that these six rivers, with all their explanatory tributaries, then converge to power a light on the macrocriminologist's hill. This is one sentence that is actually a convergence of two explanatory and two normative hypotheses to contest in further normative and explanatory research:

- Strengthen freedom to prevent crime; prevent crime to strengthen freedom.

My hope is that this is a bright light because it motivates a wide fabric of more specific propositions that weave together prospects of preventing ecocide and genocide, plus many more minor dominations. They can balance and temper commodification, punitiveness and militarisation, while enriching the meaning of freedom.

A craft of institutional weaving is my political ambition. That weaving is accomplished by a politics of struggle from below that is recursively error prone. Republican social democrats like me spend a lifetime tugging at these 150 strands in ways that sometimes cause the fabric of social democracy to unravel rather than strengthen. While this final light on the hill is recursive (with feedback loops), it is not as complexly nonlinear as the 150 propositions. This is why the 150 tributaries are more important than the unifying light on the hill. A methodological proposition is that if many lives are spent at political work on many strands of freedom, the fabric can progressively become sufficiently resilient that freedom becomes that bit easier to strengthen through another strand. It becomes harder to unravel by pulling on the wrong strand at the wrong time. This is my upbeat reading of the flawed, yet inspiring political and intellectual lives of the social movements led by Sun Yat-sen and Xanana Gusmão.

Republican normative theory can be combined with explanatory theory about which institutions prevent crime and domination to power a light on the hill because it motivates the fabric of propositions in Appendix I. 


\section{Plan of the book}

Chapter 2 argues that it is good to ask how we should treat individual victims and offenders to prevent further crime. Yet it is even better to ask how we should do so to maximise freedom and minimise domination. Then, we do well to inquire how the aggregated effect of many individual responses to crime will have structural effects. In turn, we can study how social structures enable and disable individual responsiveness of different kinds. In conditions of contemporary capitalism, the book argues that important macro questions are about how markets shape crime, how markets are criminalised and how markets criminalise other institutions such as states and, recursively, how institutions criminalise markets. By bringing to bear the multiple micro-macro lenses traversed in Chapter 2, we can think about doctrines such as deterrence, incapacitation, rehabilitation and situational crime prevention in transformed ways.

The first item of business in Chapter 3 is considering the normative order that makes criminality unthinkable for most individuals in most organisations at most times and places. It advances anomie as a central topic of macrocriminology. The proposed freedom theory of crime argues that a normative order that is legitimate because it guarantees freedom and minimises domination lays a pathway to low-crime societies.

Chapter 4 follows in the footsteps of Merton, Cloward and Ohlin and connects their writing to the theory of freedom and crime. Its hypothesis is that crime rates will be low when there are maximum legitimate opportunities to be free and minimum illegitimate opportunities to dominate the freedom of others. It reviews, reframes and reinterprets the literature on relationships between opportunity, inequality and crime. It sets up an analytical direction for building on the insights of Messner and Rosenfeld on the imperative to temper dominations of avarice with contributions from many institutions. Evidence is reviewed that places with extreme inequality tend to have a lot of crime. Inequality's criminals are freedom's termites.

Chapter 5 diagnoses how inequality empowers crimes of the powerful. Only some of the evidence that informs this analysis is quantitative. It is in the nature of crimes of the powerful that if we know about them at one point in history, they are unlikely at that point to be the most lucrative 
forms of such crime. With corporate crime, when a strategy of predation becomes well known, it becomes less lucrative. Hence, the counting of corporate crime tends to count what is least important.

Fortunately, however, at this stage in the development of the criminology of organisations, we can look back across several generations of ethnographic contributions to the study of past waves of organisational crime. These ethnographies cumulate to the theoretical insight that corporate crime and state crime are much more preventable than Edwin Sutherland used to think. The work of Farrall and Karstedt (2019) on middle-class crime suggests that unless we bring the 'crimes of the 1 per cent' to heel, anomic crimes of the middle 50 per cent-which are not counted in Uniform Crime Reports, Interpol or UN Office on Drugs and Crime (UNODC) counts of crime-might continue to take off. The chapter concludes from disparate qualitative sources that high levels of inequality in societies tend to increase crimes of those who dominate as well as crimes of the dominated. Good evidence now shows why and how. Chapter 5 proceeds to show that these insights inform how tempering the power of the most powerful officeholders in a society with power exerted by countervailing institutions can be effective in reducing crimes of the powerful. Hence, Chapter 5 nails down key institutional anomie themes. These are that separations of institutional power and reduced inequality of wealth and power can temper crimes of the powerful.

Chapter 6 considers how separated powers in the structure of a state and a society can prevent crime and defend freedom by closing off illegitimate opportunities.

Chapter 7 deals with how to temper anomic financial capital with checks and balances. In this sense, it picks up the institutional anomie tradition of criminological theory. Checks and balances come in the analysis of this chapter from other forms of capital that are critical to criminality. These checks on financial capital are human capital and social capital (and recovery capital and restorative capital as important variants of social capital). These different forms of capital are seen as checking and balancing one another in low-crime societies, low-crime markets and organisations, and low-crime times and spaces.

This is part of what we mean by tempering financial capital, making it accountable. The chapter then argues against libertarians who see a weak state as important to sustaining strong markets. It argues against socialists and institutional anomie theorists who see overly strong markets as 
a threat to an effective state. It argues for strong markets, strong states, strong civil society and strong individuals as all being important for crime prevention and domination prevention. These concepts are a challenge to define. Here is a definitional footnote that most readers can choose to skip because tweaking these starting definitions gets much attention in the body of the book. ${ }^{3}$

3 Strong individuals, from the perspective of republican political theory, are defined as individuals who can act independently of arbitrary power exercised over them. For example, if their family insists that every member of their family studies medicine, they are strong enough to choose to resist this and to say they will be a musician. Strong markets have robust competition between competing suppliers of the same products and services. This is even more difficult to operationalise. One reason is that it is fraught to define what is the same service. Do buses and trains provide the same service called transport, or do they provide somewhat different services? China and the United States have the most robust and competitive markets (even though one of them has a lot of socialism) because they are so big, with so many domestic competitors. Yet Australia has more efficient and competitive agricultural production than both these giants because there is virtually zero protection for farmers under Australia's open trade regime. But Australia has less competitive airlines and banks than the United States and China because the Australian economy is only big enough to support robust competitors in banking and airlines that can be counted on the fingers of one hand. It does not help the strength of banking markets for small economies to have dozens of banks that crash into bankruptcy on a regular basis (as most economies did during the nineteenth century). Import competition helps with international airline markets but not with domestic markets. With banking in Australia, import competition has not worked because foreign banks could not compete with the service infrastructure of local branches and mostly only served to weaken the integrity of markets. Chapter 5 discusses the Nugan Hand Bank and the Bank of Commerce and Credit International, which mostly only contributed dirty money services to the Australian economy and did not last many years before they collapsed. Hence, just counting the number of competitors, market by market, does not work to measure the strength of markets. It requires counts of the number of robust domestic competitors combined with the effective level of competition from import substitution. I will argue that it can be productive to measure the effects on crime and freedom of institutions designed to secure strong markets rather than the actual strength of markets. State strength confronts operationalisation problems with some similarities. The size of state budgets is useful, but misleading if much of those budgets is for subsidies to the private sector and/or corruption; likewise, with 'ghost employees' padding counts of public employees. This problem is not just about corruption. In some developing countries, large numbers of teachers are employed who infrequently turn up to teach children, especially in remote villages. More problematically still, measuring the size of the welfare state by the number of welfare bureaucrats can be misleading because states might improve the efficiency of getting welfare support to people by cutting the number of state officials so more of the cash goes into the pockets of the poor. The strength of civil society can be usefully measured by counts of the number of nongovernmental organisations (NGOs), but in most societies, it is not possible to know which NGOs have four members and which have 4,000 or 4 million. Peacebuilding Compared (available at: johnbraithwaite.com) aims to include such counts to operationalise civil society strength, but also codes dozens of other variables that include the Freedom House political pluralism and political participation indices, the number of journalists imprisoned, the capacity of civil society organisations, codes of Ackerman and Kruger's measures of organisational strength, access to critical resources, the strength of domestic networking and international networking in civil society with horizontal integration and vertical integration coded separately, various gender inequality and gender rights activism rankings, 'Were women's NGOs important peacebuilders?', 'Were religious leaders prominent in peacebuilding?', the frequency of a variety of civil society tactics of mobilisation including protests, strikes, boycotts, political engagement indices that measure inputs like the percentage of citizens voicing opinions to public officials, and diaspora support for marginalised ethnic minorities. 
Tempering power implies a mutually constitutive approach to each of these arenas. When criminologists bring the state back in with a broader lens than simply the state as punisher, we see the importance of states in providing, redistributing and steering. States bake cakes, slice them and regulate processes of baking and slicing. This is a social democratic and republican vision of the low-crime, high-freedom state intended to unsettle neoliberal orthodoxies. When states become criminalised, many institutions can unravel; anomie cascades and so does the risk of catastrophic violence.

Following Martin Krygier $(2017,2019)$, Chapter 8 conceives of tempering capital as akin to tempering steel. It alloys steel with other elements that not only make the steel stronger, but also render the alloyed metals more resilient. The ideal for a low-crime society advanced in Chapter 8 is one that has strong financial markets, strong human capital, strong social capital, strong recovery capital and strong restorative capital, with each deploying its strengths to cover the weaknesses of the others. No form of capital is capable of totally dominating the society in this social democratic and republican vision. Chapter 8 moves on to put into this mix strong states checking the power of strong markets, strong civil societies and strong individuals constituted by strong human capital formation. States cultivate low-crime societies when they are strong on providing (for example, public housing), redistributing (for example, tax, minimum wage laws) and regulating (for example, antitrust, anticorruption and environmental law, regulation of the state by regulators inside the state itself).

Two centuries ago, when crime rates were much higher and economies much weaker, states had quite feeble capabilities. For today's advanced economies, the government share of national expenditure in 1870 was still only 11 per cent. This had almost doubled half a century later, and then doubled again in the half-century after that to hit 40 per cent by the 1970s. It has risen only moderately as a percentage during the most recent half-century, even if hugely in absolute spending capacity, but with high variation between government shares: 36 per cent in the United States in 2019 and even lower in some other liberal economies and 55-60 per cent in more social democratic economies like Sweden (Rodrik 2011: 17) and France in 2019 (OECD 2019). A combination of shifts from neoliberalism to authoritarian capitalism and the Covid-19 crisis saw the global average for government expenditure increase sharply in 2020 - for example, to 44 per cent in the United States and 63 per cent in France and Belgium. 
Chapter 9 discusses how to make punishment effective by checking it with other institutions to the point where it is rarely used, where it is minimally sufficient for crime prevention and domination prevention. Minimally sufficient punishment that is dynamic and buttressed by dynamically escalating social supports is the ideal. It is tempered punishment that speaks softly, firmly and fairly only after gentle persuasion has been attempted again and again. This minimally sufficient account of tempered punishment is also a restorative account of punishment (which many restorative justice theorists might not recognise or embrace).

Chapter 10 develops a different vision of incapacitation in criminology. Removing the capacity of the addicted surgeon or the recklessly administrated hospital to conduct surgery captures this alternative paradigm of incapacitation. It is quite different in institutional detail in the conceptual space it shares with imprisonment as incapacitation. The chapter argues that the most important forms of incapacitation precede yet anticipate punishment and are more fundamental to macrocriminology than punishment or deterrence.

Chapter 11 argues that crime is 100 times as bad in some police forces as in others, in some communities compared with others, some markets compared with others, some organisations, some whole societies and some periods of history compared with others, because crime is a cascade phenomenon - as are domination and anomie. Because violence cascades, war tends to cascade to crime, and vice versa. We cannot understand why some societies have such criminalised states and markets compared with others without understanding histories of warfare.

Chapter 12 concludes by discussing tempered violence and tempered domination. The freedom theory of crime argues that the pacification of all forms of violence (not just criminal violence) is critical for a low-crime society. State violence looms large here as does violence in childrearing in families, in sport and in education. The argument is that it is hard to secure a low-crime society if the state is recurrently a moral exemplar of violence, rushing into wars, assassinations, torture of 'terrorists', building brutally violent prisons and accepting capital punishment and excessive use of force by overly militarised domestic policing. It draws on Chantal Mouffe's theory of agonistic pluralism to reflect on how to struggle to transform institutions against resistance from those who benefit from the 
institutional order. It argues that macrocriminology must be politicised if it is to be relevant to the prevention of accelerated extinctions, and rebellion against extinction.

Sadly, the likelihood of failure in that political project of crime prevention is high. More than most criminologists, I see crime prevention and domination prevention frameworks of analysis as central to extinction prevention and extinction rebellion. Macrocriminology might surprise by making more constructive contributions towards preventing ecocide and genocide than we expect.

\section{The research program ahead}

The core conclusions of Chapter 2 are, first, that retrieving macrocriminology would improve the field so long as it does not lose the ambition of micro-meso-macro theoretical-empirical integration; second, that freedom and crime theory is a promising candidate for that project. The conclusion that a low-crime society is a marker of a good and free society can be critiqued as rosy utopianism of all good things going together. Actually, this book conceives of them as quite likely to fall apart to the point where extinction at the hands of genocidal weapons of mass destruction and ecocide will be our fate. The book does articulate an alternative politics of hope grounded in the histories of many societies that have fostered many good things to go together to create peace, low crime and freedom. Qualitative research is drawn on to reveal why and how the good things for which good political leaders have striven often have unravelled into violence and ecological catastrophe.

General theories such as the theory of freedom and crime can be valuable in explaining macro effects. They also pick out a light on the hill that defines a healthy direction for active citizens to struggle towards. Like all general theories in a complex world, it will be wrong most of the time, at least in some important respects, and in many local contexts of application where those locales confront unique historical events. Being evidence-based should not be a copout from the obligation to study local contextual variation and to listen to local voices. General theory improves when it relishes qualitative studies of the particularities it misses or distorts in interstices of specificity. 
The concluding pages of Chapter 8 explain how the theory of freedom and crime might be tested against homicide rates, corruption levels and other crime variables cross-nationally. First, the hypothesis can be tested that thin liberal freedom, as captured by measures such as the Political Freedom Index, explains lower crime. Then we can add to the model measures of the legitimacy of the normative order (the variables of Chapter 3) and citizen acceptance of that order from sources such as World Bank Rule of Law indices and measures of legal cynicism. Testa et al. (2017) recently tested the effect of Rule of Law indices on cross-national homicide rates, finding that high scores significantly reduce homicide. The hypothesis here is that the addition of variables that measure the legitimacy, acceptance and understanding of the normative order should add to the explanatory power of the thin liberal model of freedom and crime. This first model and the 10 models that follow are all oriented to the measurement at the macrolevel of the institutionalisation of freedom and prevention, rather than to any measure of perceived individual freedom.

A third model adds Mertonian measures of legitimate opportunities being closed to many (Chapter 4). Chapter 8 makes a case for adding here a block of variables that includes overall inequality measured by the Gini coefficient, racial and gender inequality, state-sanctioned discrimination, poverty and infant mortality (because it is an unusually valid proxy for poverty in developing economies). This is rather than testing different forms of closed legitimate opportunities against one another to judge whether poverty is more important to explaining crime than inequality, for example. ${ }^{4}$

A fourth model adds Cloward and Ohlin's measures of illegitimate opportunities being open to many of the same people (Chapter 4). Measures of legitimate opportunities include the quality and inclusiveness of preschool, school, university and vocational education systems, including access to them for prisoners. Measures of illegitimate

4 Footnote 6 in Chapter 8 points out that some measures of inequality will have so much multicollinearity with others that it is best to form composite measures. But where correlations among different measures of domination are moderate, a preference is to enter them all as a block of variables. The deepest theoretical interest is in the coefficient for the whole block of variables. It is less in the correlations of individual measures of inequality with crime than it is with the multiple correlation of the block of inequality variables. This does not deny merit in replacing the block with each single variable, in one reanalysis after another, remaining open to some facets of inequality proving more empirically important than others. Extant research suggests these facets will be quite different for explaining crime than for explaining war, though some, like gender inequality, may be equally important to both. 
opportunities include the comparative size of underground economies (such as drug markets and cash flows that cannot be accounted for in the legitimate economy). Chapter 8 argues that the size of dark markets may also be a measure of crime that feeds back to explain other types of crime that it does not measure.

To the measures of human capital in the previous model, a fifth model can add measures of the strength of social capital (including recovery capital and restorative capital) (Chapter 5). In other words, this fifth model adds a block of social capital variables.

A sixth model adds measures of the strength of the state, of markets (especially markets in crime prevention and domination prevention), of civil society and of individual autonomy (Chapter 7). Some institutions of civil society are more important than others according to the theory. For example, a strong women's movement is particularly important to crime reduction and domination reduction.

A seventh model adds measures of how strong more specific institutions are-such as families and the education, health and welfare systems that are identified by the insights of institutional anomie theory (Messner and Rosenfeld 2013) (Chapter 8). Social housing is an example of a particular facet of welfare institutions that is identified as particularly strategic for domination reduction and crime reduction in the freedom theory of this book.

An eighth model adds a block of variables that go to how richly separated are the separations of powers (Chapters 6 and 8). It seeks to rise to the difficult challenge of measuring contestation among different forms of capital and different kinds of institutions, picking up a variety of measures of checks and balances. While as basic an institution of freedom as the holding of elections is captured by the Political Freedom Index in Model 3, checks on this by institutionalising a politically independent electoral commission are a facet of Model 8. This is a test of the hypothesis that there will be less crime when all forms of power are tempered by other forms of power (Chapters 7 and 8). The strength of business regulatory institutions is an important addition in this eighth model.

A ninth model adds measures of the pacification of noncriminal forms of violence (frequency of participation in wars, physical punishment in schools, torture and corporal punishment in the criminal justice system 
itself and other forms of violent state crime, brutality of the prison system, the popularity of violent sports) (Chapters 7 and 11). Or it might consider these variables separately.

A tenth model would measure the strength of social movements for nonviolence in societies, the depth of sophistication of the institutionalisation of political strategies of nonviolence and the cascading of nonviolence-matters the Peacebuilding Compared project is particularly well designed to capture (Braithwaite and D'Costa 2018).

Each of the foregoing 10 models, according to the theory of freedom and crime, will explain more variance than the model that precedes it. They should explain according to the theory not only variation between societies in levels of homicide, robbery or burglary, but also levels of corruption, tax compliance and environmental stewardship cross-nationally. The challenge of measuring crimes of the powerful meaningfully remains daunting, but it must be tackled creatively where it can.

The theory hypothesises that an eleventh model will not add significant variance in explaining either crimes of the powerful or crimes of the powerless. This involves adding a composite measure of the punitiveness of the justice system for each country (the most important measures being the imprisonment rate and the frequency of executions) (Chapter 9). The theory of freedom and crime stipulates monitoring whether tougher deterrence is necessary for crime prevention. If the outcome is that societies with modest levels of punishment do not have higher crime rates then this is important validation of the hypothesis that freedom for offenders and their families can be enhanced by lower levels of punishment without jeopardising the freedoms of crime victims, present and future.

Of course, the real world of developing, elaborating and testing theory is more iteratively responsive to emergent pattens and clusters of variables in data than any predetermined sequence of 11 models. The hope is to complete the Peacebuilding Compared data collection by 2030. Data gathering has been under way since 2004 and includes the demands of fieldwork on the ground by me and others in each locale that has experienced a war. In 2030, the plan is to undertake the foregoing kind of stepwise analysis of Peacebuilding Compared. It will study war zones and war and crime recurrence, in preference to whole societies. Other datasets can grapple with similar kinds of analyses that would in some way be 
superior to a completed Peacebuilding Compared dataset, and in other ways inferior, especially on the war-related variables that are unusually important in this book.

The next few chapters turn away from the quantitative work Peacebuilding Compared will undertake to test these 11 models. Peacebuilding Compared and the macrocriminology of this book are both fundamentally dependent on qualitative work that connects events in very local spaces to global spaces, and historical work that is both fine-grained in its focus on critical junctures and of wide sweep across the entire history of the planet.

Chapter 12 draws on the scholarship of Chantal Mouffe to reflect on what kind of agonistic pluralist politics is required to struggle against existing hegemonic formations that would defend the status quo against the kind of transformations proposed to expand freedom and reduce crime. The conclusion describes the kind of society for which criminologists might struggle if further research supports the theory of freedom and crime. It would require minimally sufficient deterrence and maximum social support for relational prevention. It would require defence of a thick republican conception of freedom that takes domination more seriously than is the case in existing societies, while joining hands to a degree with those who would only go so far as to defend thin liberal freedom.

The theory of freedom and crime would require a global institutional imagination against the resistance of capital to build strong welfare states, strong labour rights, human rights and redistributive tax policies. It would give crimes of domination greater prominence in the normative order over crimes of the dominated, especially war crimes, environmental crimes and crimes of capitalism that risk the collapse of liberal forms of capitalism into the tentacles of authoritarian capitalism. The struggle for nonviolence, AMP (Awareness, Motivation and Pathways) away from cascades of violence, peacemaking and preventive diplomacy would be crime-prevention priorities (Honig et al. 2015). The theory of freedom and crime requires greater investment in building strong individuals and strong civil society through community development for collective efficacy, youth development circles and restorative justice that forms democratic citizens in families, schools and workplaces to ripple out social capital and CHIME (Connectedness, Hope, Identity, Meaning and Empowerment). According to the freedom theory of crime, relational restorative justice values that emphasise healing and love build more freedom and less crime than punitive thought about justice. 
This is a lot for criminologists to be concerned about. It conceives of criminologists as having a heavy burden as stewards of their field. Criminologists are students and custodians of freedom and of the canary in capitalism's coalmine. Crime and punishment are that canary; compliance with legitimate, freedom-enhancing laws is a sign of that canary's health. Crimes of the dominated and crimes of domination-especially those that might trigger cascades from capitalism to despotism, from capitalism to ecological collapse, to accidental nuclear war, to intentional wars with killer robots and chemical weapons-are fates that macrocriminology might help our fragile planet to escape. By responding to that challenge, we might contribute to the survival of humankind. Let us be pessimistic and assume that the analysis in this book has but a few grains of truth. Even then, criminologists have redemptive responsibilities to attempt more meaningful macrocriminologies to add a few more grains. Then they might act on them towards a freer, safer humanity that struggles with fewer extinction threats. 
This text is taken from Macrocriminology and Freedom, by John Braithwaite, published 2022, The Australian National University, Canberra, Australia.

doi.org/10.22459/MF.2021.01 